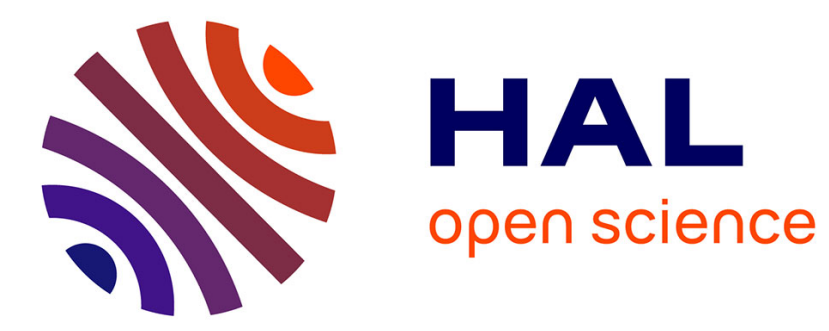

\title{
Co-management of fisheries through a negotiation lens: The case of prud'homies
}

Yazdan Soltanpour, Iuri Peri, Leila Temri

\section{To cite this version:}

Yazdan Soltanpour, Iuri Peri, Leila Temri. Co-management of fisheries through a negotiation lens: The case of prud'homies. Maritime Studies, 2020, 19 (2), pp.167-178. 10.1007/s40152-020-00165-3 . hal-02491206

\section{HAL Id: hal-02491206 https://hal.science/hal-02491206}

Submitted on 26 May 2020

HAL is a multi-disciplinary open access archive for the deposit and dissemination of scientific research documents, whether they are published or not. The documents may come from teaching and research institutions in France or abroad, or from public or private research centers.
L'archive ouverte pluridisciplinaire HAL, est destinée au dépôt et à la diffusion de documents scientifiques de niveau recherche, publiés ou non, émanant des établissements d'enseignement et de recherche français ou étrangers, des laboratoires publics ou privés. 


\title{
Co-management of fisheries through a negotiation lens: The Case of Prud'homies
}

Yazdan SOLTANPOUR 1,2 , Iuri PERI 1, Leïla TEMRI 2

1 University of Catania, Department of Agriculture, Food and Environment, Catania, Italy

2 MOISA, Montpellier SupAgro, CIRAD, CIHEAM-IAMM, INRA, Univ Montpellier, Montpellier, France

E-mail and telephone number of corresponding author: 2 place de Pierre Viala, 34060 Montpellier, France.

yazdan.soltanpour@supagro.fr, 0033767551356

\begin{abstract}
While the European Union's fishing policy is mainly based on maximum sustainable yield, at the local fishing community level, fishers' main incentive to sustain fish stocks appears to be maintenance of social relationships. Divergence of stakeholders' objectives on the management of marine resources creates conflicts of interest that can be overcome through a process of negotiation. The formulation of the solution is embedded in the perspective of the stakeholders. In this paper we analyze the negotiation mechanisms between the French Mediterranean local fishing communities and the European Union common fishery policy. Inspired by interactive governance theory, the performance of Prud'homies, a local governance entity in the French Mediterranean, has been analyzed through their capacity to cooperate and represent the fishers' voice in formal institutes. We are witnessing a declining representation of this local institute among the official decision-makers of the marine resource governance.
\end{abstract}

Key words: Participation, voice, local fishing community, interactive governance

Acknowledgments: We acknowledge the European Commission under Erasmus Mundus Joint Doctorate Programme: “Agricultural Transformation by Innovation (AGTRAIN)” and the financial support of University of Catania in the framework of the project "Economic assessments of the sustainability of agri-food systems" WP1 - Sustainability of local agri-food systems and fisheries - 2016/2018”, coordinated by Peri Iuri. A special thanks to Michaël Trope, of National Institute of Agricultural Research at SupAgro-Montpellier and to all the fishers and official organizations of fishery involved in the case study area.

\section{Introduction}

As the issue of sustainable management of marine resources becomes critical, more attention is directed toward re-engagement of traditional management tools. One such tool is community fisheries management. The Green Paper (EU 2009) suggested regionalization as a strategy to overcome failures within the common fishery policy's (CFP) decision-making system (Salomon et al. 2014). Incorporating a wider range of stakeholders in the decision making aims to increase the legitimacy of the regulations and guarantee their implementation. Co-management in this context is defined as the sharing of power and responsibility between the government and local resource users 
(Berkes 2009; Carrà et al. 2017). However, governance problems in fisheries are often 'wicked' (Rittel and Webber 1973; Vindigni et al. 2016). There is no optimal solution, and the formulation and existence of the problem are deeply embedded in the perspectives of the stakeholders (Rittel and Webber 1973; Whyte and Thompson 2012). The dynamics of human-in-nature systems (or social-ecological systems) raises issues of resilience, adaptation and transformation and requires changing the focus from seeking optimal states and maximum sustainable yield to co-management (Jentoft and Chuenpagdee 2009), capacity of self-organization (Folke et al. 2002) and resilience analysis (Holling 1973; Walker et al. 2004; Monaco et al. 2019).

Accepting fisheries as social-ecological systems (SES) reinforces the notion that fisheries need to be managed by addressing problems related not only to the resources themselves but to the people exploiting them (Hilborn 2007; Gutiérrez et al. 2011). The community level is important as the starting point for the solution of the tragedy of the commons (Berkes 2006). Viable fish stocks require "viable fishing communities" (Jentoft 2000). "Before one can hope to rebuild fish stocks, one must start to rebuild communities; one cannot succeed without the other" (Jentoft 2000: 53). Viable fishing communities are able to cope with challenges (Hechter and Horne 2008) either in the political sphere or in the natural environment. The survival of the fishery and community viability have always been, and still remain, a consequence of an adequate level of flexibility (Broch 2013). The resource collapse is highly probable in open-access sources where the resource users are diverse, do not communicate, and fail to develop rules and norms for managing the resource (Ostrom 2009). Governability here can be rephrased as the capacity of fisheries as a whole to self-organize and maintain themselves with due consideration of the inherent and constructed qualities embedded in nature and society (Song and Chuenpadgee 2015; Berkes and Nayak 2018). While in the top-down pyramidlike fishery governance system the fishers are passive recipients of regulations, in the alternative community based management system fishers serve simultaneously as subject and object of governance (Jentoft 2006; Berkes and Nayak 2018). Governors whether of the state or of the fishing population - need to balance between different policy objectives and between the imperatives of inclusion and exclusion to improve governability (Bavinck et al. 2015).

Interactive governance theory provides the conceptual thinking of this analysis. In the "interactive governance theory" it is argued that fisheries and coastal governance is basically a relationship between two systems, which could be termed a "governing system" and a "system-to-be-governed" (Bavinck et al. 2013). The former system is social: it is made up of institutions and steering mechanisms (Kooinam and Chuenpagdee 2005). However, although few studies have already applied interactive governance theory to fisheries, its lack of conceptual reasoning and tools in discussing matters such 
as power and marginality has been criticized $^{1}$ (Scholtens 2016 In Song et al. 2018). We may determine the negotiation between the state and the local community by analyzing the role of interest groups and their influence on the final policy outcome (Markussen and Svendsen 2005). The relevant question would be: what role does each actor of the fishing governing system play in the management of the marine resources? The power of each actor, measured by its voice in the decision-making, determines their actual role in the governing system. The SSF, regional and national delegations, and the EU legislation framework each play their pre-defined role in the management of resources. The marginal changes (increasing or decline) in the power can be taken for this analysis. These changes may lead to gradual exclusion of certain actors and/or their replacement with other emerging authorities. To reach this goal, we address 1 ) the dichotomy between the European and community-based regulations and 2) the position of Prud'homies in co-management of marine resources in the current European context using a lens of negotiation theory.

\subsection{Society - community dichotomy}

The community/society dichotomy (Gemeinschaft/Geselleschaft) was first introduced by Tönnies (1887). He introduced two levels of order that are not mutually exclusive. In the case of SES, we may add a third level: an ecological system that determines the environment of interaction between the two classes of actors (the society and the community). This consideration can also be seen in the study of other behavioral and social sciences dividing the analysis into three levels: (I) the individual human agents constituting (II) a society as a part of a (III) (supra) regional social-ecological system (Solich and Bradtmöller 2017). According to Reynaud (1997) there are two organizational systems that coexist. The first one is a control system which is based on the logic of efficiency and cost-benefit management and the second one is based on affection relations and feelings. The first one leans on regulation and the second one covers the practical reality. The incompleteness of control regulations leaves room for local norms to develop. In other words, the flexibility of local norms allows the control regulations to work properly. The two reach a consensus to enable them to interact. Another point of view addresses the relation between community and the global regulations as "roots-and wings" suggesting a balance between inward and outward perspectives: "We obviously need the roots that community provides, but we also need the wings that globalization both grants and requires. We need robust communities that instill in people a solid identity. We need communities for the permanence and stability they provide" (Jentoft 2011 p.20).

\subsection{The two main parties in fishery management}

1 For a complete discussion on tools for assessing the changes in the governing system and the system to be governed refer to Chuenpagdee and Mahon (2013). 
The local community and the control regulation system are the two main components of the fishery governing systems. The goal of the control regulation system is to influence the interaction between the social and the natural sub-systems that are to be governed in order to halt ecological degradation (Jentoft 2006). The goal of the fishers, on the other hand, is to maintain the social relations of the fishing community, and their behavior (both individual and collective) is guided by a diversity of relationships such as dependency, obligation, support, reciprocity, exploitation and collective action (Pollnac, 1988; Jentoft et al. 1998; Coulthard 2012). From the coexistence of these two regulatory components of the fishery system emerges interactions where each has to renounce a part of its goals to reach a mutual consensus. In the context of a democratic society, as rules have to be in accordance with the wills of the majority, the control regulation system attempts to attract more supporters and thus represent itself as the majority's will. Politicians ask for advice only to support and legitimize their preformed political decisions (Hoppe 2005). In this process, one party, in order to convince the members of the other group or to attract their support, has to assure that their activity does not cause any harm or would compensate in case of any. They would need the popular consent for actions they take. In this context, the actions that are fulfilled are outcomes of negotiations between agents of the community and the society's regulative system and not driven from a participatory decision making process as it is advertised by many defenders of co-management. Fishery management, to date, mainly serves to satisfy the needs and aims of large-scale vessels targeting both demersal and small/large pelagic fish, and not SSF which is more rooted in fishery communities (Raicevich 2018). Fishers will engage when invited, but they do not seek out engagement of a strategic partner who must be included as part of the solution, as they report that they often feel that they are targeted as the "cause of the problem" or the "bad guy" by conservation and environmental advocacy groups (Pomeroy et al. 2016).

\subsection{Case study}

The west side of the French Mediterranean littoral is characterized by a shallow and double shore, with an area of 65 thousand hectares (Cepralmar 2013) of lagoons behind the coast of the sea, of which 10 thousand hectares of it consists of Lagoons located in the case study (Fig.1). Gulf of Lion, on the south-western Mediterranean coast of France, is among the richest fishing areas of Mediterranean Sea, which at the same time is plagued by pollution (Meyer 2000). The biological cycles of lagoons, through their interaction with the sea regulate fishing activities and also the social organization of the fishing communities of lagoons (Giovannoni 1995). Lagoons are enclosed common-pool resources which raise the importance of governance much more than that of the open sea. Its resources are managed by an institution particular to French Mediterranean coast, the Prud'homie of fishers (refer to the next section for further information). Their embeddedness in the territory has allowed them to survive changes through centuries. They take into account short- and medium-term changes in the availability of resources and set rules that are accepted by fishers (Decugis 2015). However, the changes in the fish stocks and the European policies, which have left progressively less space for local 
management, have put their future into question. In this paper, we discuss the interactions of stakeholders active in the management of lagoons of Thau and Or in south of France (Fig.1).

Figure. 1: Area of influence of three Prud'homies of case study

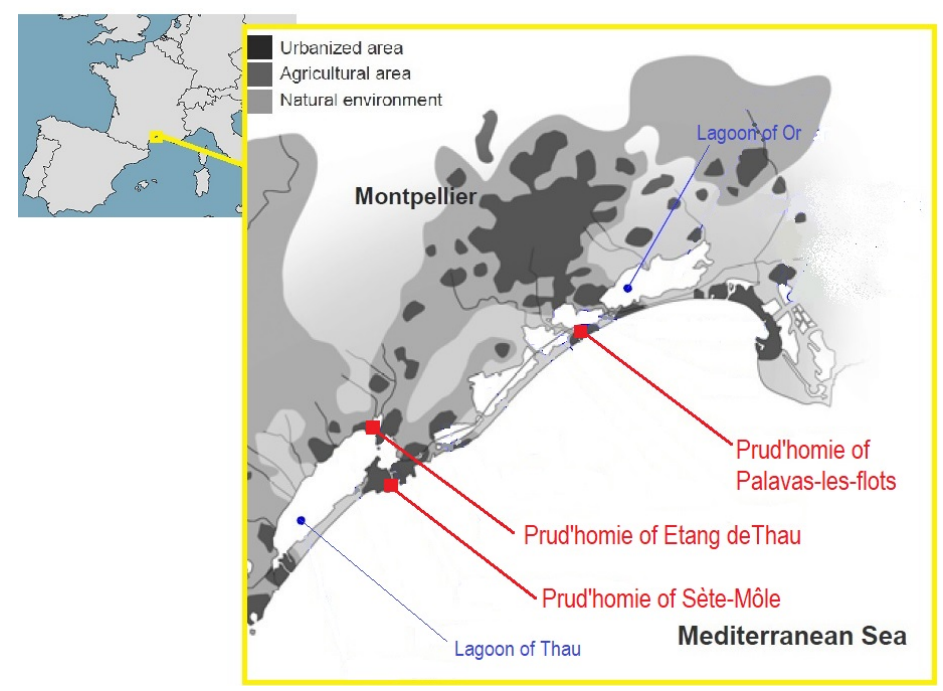

The sovereignty of state over French maritime area has been officially registered by

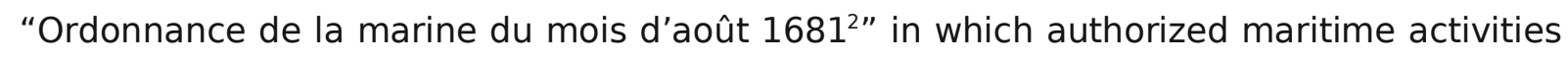
have been specifically determined. The French Constitution of 1852, despite several modifications, is the general framework of coastal fisheries exercised today. The Law $\mathrm{N}^{\circ}$ 85-542 (22 May 1985) calls for harmony with the European regulations especially on the issue of management and conservation of natural resources, at the same time allowing the state council to make decisions when necessary.

The evolution of small-scale fisheries' organization is considered a crucial topic in assessing the industrial versus small-scale division (Johnson et al. 2005). Therefore, the target of this study is specifically small-scale fisheries (SSF), as large-scale fisheries (LSF) are rarely tied to a community (Berkes and Nayak 2018). In small-scale fisheries, community is affirmed by notions of fairness, shared systems, kinship connections, locally adapted legal systems and shared attachment to place and profession (Johnson 2018). Although community values are constantly being eroded and communities are often at risk of losing their identity (Jentoft and Eide 2011; Jentoft and Chuenpagdee 2015), there is a distinction between the management of LSF and the organization of SSF in scientific literature and also political texts due to the role of community in the governance of SSF.

\subsection{Prud'homies}

The Prud'homies are democratic institutions of boat owners in the French Mediterranean coast. There are 33 fishing Prud'homies on the French Mediterranean coast. According to Chaboud et al. (2015), their birth can be explained by the presence of a large number of lagoons on this coastline and the necessity to manage the activity of different fishing gears within lagoon's territory. The complexity of managing Mediterranean fisheries was

2 P. Osmont, Paris

3 Modifying the decree of 9 January 1852 on the exercise of marine fishery. 
such that in 19 November 1859, some responsibility of coastal authority was officially assigned to Prud'homies. By this decree, decision making authority on "all organizational matters and precautions that, due to their variety and their diversity, were not foreseen in general and specific texts on the authority of fishing," was given to Prud'homies (Article 17 of Decree of $19^{\text {th }}$ November 18594). Based on ethnological studies (cf. Berthelot 1868 and Giovannoni 1995) their juridical autonomy goes back to ancient Greece. Similar organizations can be found in the Mediterranean coasts of Spain (Cofradias) and Venice (Fraglie) (Raicevich et al. 2018). The Prud'homies manage the fishing community as a mutual society. The society comprises the boat owners that are registered as a fisher. In order to be eligible to fish in the lagoon, in addition to being registered at the delegation of sea and coastal affaires (Délégation à la mer et au littoral, the official organization of maritime affaires), one has to be a member of Prud'homie.

In this study we address three Prud'homies which have been selected as a sample. Though the three are registered officially under the administration of the Port of Sète, their attributes are distinctive. One is only active in the management of lagoon of Thau (Etang de Thau), the second Prud'homie (Sète-Mole) is located at the port of Sète and includes not only SSF but also trawlers and tuna fishing boats operating exclusively in the sea. The third Prud'homie (Palavas-Les-Flots) operates in both areas of lagoon and sea. The other 30 Prud'homies are similar to the third case. We have intentionally included cases that are exclusively active in lagoon and that which is only active in sea (the first and second case) to check different ecological environments. The three Prud'homies are from the regulative point of view similar, but have gradually adopted managerial strategies due to differences in the social-ecological environment.

Table 1: Three cases of Prud'homies

\begin{tabular}{|c|c|c|c|c|c|}
\hline \multirow{2}{*}{$\begin{array}{l}\text { Name of } \\
\text { Prud'homie }\end{array}$} & \multirow[t]{2}{*}{ Place of activity } & \multicolumn{4}{|c|}{ Number of active vessels } \\
\hline & & $\begin{array}{ll}\text { SSF } & - \\
\text { Lagoon } & \end{array}$ & SSF - Sea & Trawlers & $\begin{array}{l}\text { Tuna } \\
\text { fishing }\end{array}$ \\
\hline Etang de Thau & Lagoon & 170 & - & - & - \\
\hline Sète-Mole & Sea- Coastal and offshore & - & 30 & 16 & 15 \\
\hline Palavas-Les-Flots & Lagoon and coastal & 19* & 19 & - & - \\
\hline
\end{tabular}

*Among the 38 fishers of Prud'homie Palavas-les-flots there are 10 fishers who fish in both areas of lagoon and sea

Source: Interviews (2019)

Every three years, fishers choose three to eight representatives (Prud'hommes) to lead the fishing community. The idea of having Prud'hommes (the leaders who manage the Prud'homie) is to benefit from the guidance of the wisest among them. The prud'hommes are the elected fishers who take the responsibility of solving the conflicts among the fishers in the fishing area. Concerning the surveillance and justice, there is almost no action required to be carried out by the prud'homial institute due to the self-governing manner of fishers (Giovannoni 1995).

\section{Methodology}

4 Regulations on maritime coastal fishery in the 5th maritime area (arrondissement de Toulon). 
Understanding how micro-level behaviors of heterogeneous actors, their interactions with other actors and their biophysical environments give rise to different forms of self-governance requires a disaggregated approach (Lindkvist et al. 2017). Dividing the fishing governance system into two levels, the regulative level and the community level, has allowed us to specify the interactions occurring in each level separately and interactions between the two levels. Nevertheless, this paper is specifically interested in the interactions that happen between the two levels of governance: local fishing communities (the Prud'homies) and the EU regulative entities.

To understand some of the essential challenges that confront any collective action we need a "thick description" of the context (Geertz 1973). In order to discuss the potential of co-management in the Mediterranean fisheries, one should answer the question of: "who loses and who benefits from the social-political changes (going further towards centralization of decision-making or regionalizing) in the fishing system?" This full and detailed picture of what happened in the past is useful to explain how organizations evolve and what shape they would assume. Oral history, field observation, interviews and focus groups are used to obtain detailed and specific information about individuals, households and communities (Chuenpagdee and Mahon 2013). For this purpose, a timeline is drawn with the participation of a group of fishers in each Prud'homie to track the historical trend of social change. A timeline is a participatory data collection tool for gathering longitudinal data on the history of a community. The topic of the research is analyzed through the sequence of key events. Small group discussions are preferable to individual one on one data collection, because they encourage discussion and are a better representation of collective community experience and knowledge. Since the Prud'hommes are elected by fishers to represent them in the management of the fishing community, we consider them the most knowledgeable fishers who are able to describe the important events of the community in the studied matter since the earliest date they recall to present. The timeline provides a different form of presentation of the topic, altering the interaction from oral to visual mode (Sword-Daniels et al. 2015). A0 size (841-1189 mm) sheets of paper with a line marked with points in equal intervals, each representing a year, were placed on the center of a table with participants having control over it, leaving one to take charge of taking notes on the sheet. The discussions were conducted in French by the lead author. Some interviews were audio-recorded and some were recorded by handwritten notes apart from the main large sheet.

In the following section of results, we present the actual and previous position of the Prud'homies regarding the rest of fishery governance system. Historical evolution declared by the active and older members of fishing community are presented. The following section discusses the strategies that governing systems adopt in order to survive in the degrading marine ecological system.

\section{Results}

The timelines drawn pointed out certain commonalities. Issues such as epidemical decline in the fish stock due to effluent of large neighboring cities into the lagoons, cultural changes in the consumption patterns of the fishers who require higher revenues, regulations imposed from the national and European Union levels concerning the fish quotas and fishing licenses, market regulations such as interdiction of selling European 
Eels to non-European countries were raised. Issues related to the co-management of lagoons and coastal area were discussed in depth with key informants who were involved in the decision-making framework as fishers' representatives in the regional fishery institutes. The issues raised in interviews were further investigated in official documents and scientific works. The results and the discussion that follows are confined to the interactions between the Prud'homies and the formal authorities, their negotiation channels and the changes that have occurred in concerning the position and power of each stakeholder in the decision-making.

\subsection{Stakeholders of fishery co-management}

After years of practicing a top-down approach to fishery management in the European Mediterranean coast, in 2002 the common fishery policy (CFP) reform proposed the establishment of Regional Advisory Councils (RACs) to 'advise the Commission on matters of fisheries management in respect to certain sea areas or fishing zones' (Commission for Environmental Cooperation 2002, Article 32:27). In this regard the Mediterranean Advisory Council (MEDAC), headquartered in Rome, transfers the new sub-regional fisheries' management plans in the Mediterranean coast to the European Commission so that the contextual differences would be included in the commissions' decision making. In this arrangement, the RACs are only advisory bodies, not management bodies with the authority to make decisions (Gray and Hatchard 2003).

There are few challenges for the survival of SSF identified in the context of our case study. The decline of marine resources in recent decades is associated with the pollution of water of the lagoons and coastal area. However, the rarity of fish, either due to pollution or to overfishing, is an issue that fishers are willing to cooperate with other entities to resolve. These topics are the negotiating subjects between the Prud'homies' representatives and the regional authorities. There have been agreements developed around the lagoon of Thau in this regard (refer to "Contrat de gestion intégrée 20122017", Syndicat mixte du bassin de Thau), in which the voice of Prud'homies among representatives of official entities (city council, regional committee of fishery, water agency, ...) seems to be low.

\footnotetext{
"Our challenge is an act of resistance in the face of changing regulations and market forces" (Prud'homme of Palavas).

"The decline of the number of fishers puts in jeopardy the existence (loss of credibility) of all the organizational structure around the fishery (Prud'homie, regional committee, fish auction hall, cooperative). It's the tax which pays for these organizations and the connection between the fishers maintains these" (a member of regional committee of fishery).
}

The SSFs are aware of the importance of the continuance of their activity from the eyes regional authorities. Higher number of fishers would be beneficial to the official institutes 
that govern the fishery and the fish market. However, reaching a consensus that creates a win-win situation seems to be a challenge, as the regulative system and the community are not necessarily complementary aspects of the same rationality of governance, but pertain to different governance problems potentially in competition (Crawford 2001).

\subsection{Types of interactions}

Gutiérrez et al. (2011) have categorized co-management in three types: consultative (consultation mechanisms and dialogue); Cooperative (cooperation in decision making); Delegated (delegated responsibility to users). Based on the questions posed regarding the structure of decision-making and the significance of the Prud'homies' role in making decisions and their application, we identified which type of co-management is applied in the Mediterranean context. The nature of regulations in different levels of social life requires a distinct category of co-management. We observed all the three types present in the French Mediterranean context. However, each type had a different weight in different levels of decision-making.

\subsubsection{Inter-communal interactions}

The cooperative co-management can be observed in the general assembly and the thematic sessions organized by each Prud'homie to resolve the problems of the marine territory under their governance. However, they delegate the power of interference to the port authority (capitainerie) in case of tensions between the member of Prud'homie and the other boats (recreational and illegal fishing boats).

“The connections (between the SSF under prud'homial governance) made that they regulated the matters among themselves, there was no need for the presence of an authority" (a marine gendarme in the case study area).

In the absence of conflicts between the fishers, the main role of prud'hommes is to lead the community towards a sustainable exploitation of marine resources. The sustainability of fisheries depends on the organization of fishers and their related activities (shellfish farms, urban area workshops etc.). The prud'hommes, considered the wisest men of their community, are elected to represent the community in the regional organizational entities and to negotiate for their well-being. Leadership is not only about resolving conflicts and distributing the fishing area but about guiding the fishing community toward a sustainable extraction of resources, where all those families in need can carry out an honorable living (Giovannoni 1995). Prud'homies represent a strong identification between a community and its fishing territory (Cazalet et al. 2013).

\subsubsection{Prud'homie - regional organizations interactions}

The emergence of other official institutes (producers' organizations, cooperatives, Regional Fisheries Committees and National Committees) reduce Prdu'homies' authority. The institutional changes of 1992, 1998 and 2010 accorded to the Regional Committees the power of managing the area within 12 nautical miles. The 
influence of cooperatives and producers' organizations which their members are mainly the trawlers and the tuna fishing boats, restricts the voice of SSFs. The area of influence of Prud'homies has been reduced to the local level and the management of resources in lagoons. While Prud'homies are attached to a port and originally to a village, they have weak representation at the local level (Bertrand Cazalet, secretary and legal adviser of SSF syndicate of Languedoc Roussillon). These institutional changes discourage the development of Prud'homial managerial concepts. At one time Prud'homies were viewed as a model to be generalized to the French Atlantic and the North Sea façade (Teran Perez 2000). SSFs face a paradox of wanting to conserve their perpetual agreements while they are aware of the on-going change in the political structure and the decision making processes.

"We need to follow the changes, at the same time respecting the laws that were valid in the past" (a Prud'homme in the case study).

Concerning the SSF of the lagoons, Prud'homies function as a single unit, while trawlers and tuna fishing boats active offshore act as individuals in the large context of the fishery. This fact is more tangible in the case of the second Prud'homie (Sète-Mole) as the trawlers and tuna fishers make up the majority of the members and the few SSF member of this Prud'homie act also independently as there is very little to be coordinated. The fishers of the lagoon, on the other hand, need to organize the placement of their gill nets, which is determined by random drawing in an annual meeting in June. It seems that the evolution of European policy is compelling SSFs of the lagoons to act as individuals, not as a unit. Applying equal legislation to all categories of fishing vessels creates a competition that in order to survive you have to defeat all others. This is in contrast with the cooperative philosophy of community based management practiced by Prud'homies.

"Coupling the fishery of European eel (Anguilla) with the same restricting regulations of other fisheries, such as threshold of motor power and the vessel tonnage, is not pertinent, as it's not the boat which fishes, it's the fisher" (a fisher of lagoon of Thau).

Transferring certain charges to the official port entities (e.g. gendarme of the sea, port authority (capitanerie) departmental directorate of the sea (affaire maritime)) gradually reduced the responsibilities and the collective choice power of the lagoon Prud'homies. The general assembly and thematic meetings are reduced to certain operational rules that usually concern the placement of the nets. Entering the lagoon as a fisher is no longer determined solely by the decision of Prud'homies, but by quotas defined at the national and regional level by the EU (EC 2002). Concerning the fishing quota, it is only applied to the tuna fish and the fishing effort of trawlers. These restrictions have been applied after a phase of three years of data collection by the port authorities. Registering the landings are seen by the SSF as an attempt by the EU to apply restrictions on their activities.

\section{Discussion}

In the following section, different types of interactions between the local and social level entities are discussed. The fundamental contrasts between the sovereignty of state and people is taken as the foundation of negotiation and its outcomes are reflected in the 
inclusion/exclusion of one party in/from the legislative framework. First we discuss the role of negotiation in co-management, and then the cooperative behavior between the members of the system, the said synergy, social capital or social cohesion is discussed under the title of inclusion in governance. Finally, the voice and the influence of the community on the control regulations is discussed.

\subsection{The role of negotiation in co-management}

Ecological or political changes continuously cause the human environment to evolve. As long as things continue as before, or at least as they were expected to, there arise no new problems requiring a decision, no need to form a new plan (Hayek 1980). But as the human society is dynamic, the position of individuals keeps on changing. Win-win situations, however rare, are achievable in well-coordinated situations where the actors can anticipate the actions of their counterparts. If the change is coordinated and wellorganized, the benefit would be distributed fairly among the actors. Otherwise, either the desired change would not take place, or one would gain more at the expense of others. Thus, for social order to arise and be maintained, two separate problems must be overcome: people must be able to coordinate their actions and they must cooperate to attain common goals (Hechter and Horne 2008). The desire of interchange can be clearly seen in the two sides. First, on the EU side, facilitating the creation of Fisheries Local Action Groups (FLAG) is an attempt to engage in conversation with the local communities. This role has been played partially in the past by organizations such as Cofradías (in Spain), Prud'homies (in France), and Fraglie (in Italy). However, the composition of FLAGs is broader (i.e. not only fishers, but also representatives of the public, private and civil society sectors), and their objectives are more focused on increasing employment and territorial cohesion rather than on local based management of fishery resources (Raicevich et al. 2018). On the other hand, in light of globalization and the need of support, the Prud'homies have tendency to negotiate the functional specifications.

Negotiation between the actors is the heart of co-management (Borrini-Feyerabend 2000). Social-ecological systems don't have a single, optimal or clear solution. They are considered as "wicked problems" (Rittel and Webber 1973). They have innumerable possible solutions (Norton 2012; Whyte and Thompson 2012), there are no right or wrong solutions because there is no end point and no stopping rule (Jentoft and Chuenpagdee 2009). Therefore, there is a constant negotiation between the agents (institutions, social norms and others) seeking to improve the previous agreement. We have employed the definition of negotiation proposed by Stephenson (1984) that has been employed mainly by researchers in the domain of management, conflict resolution and organizations: a process putting two or more actors face to face who are confronted with divergences and recognize their interdependence, choose to search for an arrangement to come up with a new equilibrium, although temporary. Members of a local producers' organization may not be specialized negotiators, however, they make daily deals which could be considered negotiations (Fisher and Ury 1982). Human relation is full of mutual and collective agreements. The majority are not written down and signed by the concerning parties, but there are verbal 
consents indicating simply "if you do this, I'll do that." Even some agreements may be carried out by a simple eye-contact or a nod of the head. In all cases, the agreements will govern the interactions between the involved parties.

Negotiation is a remarkably important issue in the management of CPR. Its importance is more comprehensible when a problem arises, which if not resolved usually leads to the tragedy of commons (Hardin 1968). Almost from its inception, the literature on co-management observed that stakeholder self-organization arises often in the context of crisis, conflict, and competition (Pinkerton 1989; Mahon et al. 2008). Early social theorists such as Cooley (1918), Simmel (1955) and Coser (1956) saw conflict and cooperation as two sides of the same coin that combine to give structure, meaning and direction to social life (Eggins 1999). Both the degree to which a community is capable of self-organization and their capacity to learn and to adapt to an ever changing environment strongly depend on trust and social capital as well as on the degree to which the community is authorized to change its own rules (Ostrom, 1990; Baland and Platteau, 1996; Agrawal 2002; Vollan 2008). A system which cannot generate from within itself the conditions for its own change cannot produce the rules for the change of its own rules (Watzlawick et al. 2011). Communication and interaction between different levels of systems of governance is required to stimulate the change.

Synergy is a concept that has been used to explain sociological interactions, both as an outcome and as a mean through which more constructive relationships are fostered (Pascual-Fernández et al. 2018). In the context of interactive governance (Kooiman et al. 2005), synergy is a possible outcome of interactions that occur between the governing system and the system that it aims to govern, as well as internally to both systems. In this case the synergy attained helps create resilience in times of crisis and has proven to be a basis for community sustainability (Pascual-Fernández et al. 2018). When a culture is highly resistant to change and culturally tight, then those who have the least in common with the mainstream are the most likely to be marginalized (Lassiter et al. 2018). Although scholars using the co-management theory are clearly and deeply concerned with the marginalization of small-scale fishers, we still lack a conceptual reasoning and proper tools to analyze the (re)production of marginality" (Scholtens 2016 In Song 2018).

\subsection{Exclusion/inclusion in governance}

Inclusion has been employed as a social indicator that identifies the quality of fishery system. At the local fishing community level, the opportunity of being a fisher is determined by the agreements held at the community confined to a larger frame of the society. Inclusion is usually defined by its opposite, exclusion, which is then often regarded as a synonym of poverty. However, social exclusion is a relational and multidimensional notion contrary to poverty which largely refers to a lack of material resources (Picker 2017). From this perspective, the access to fishery grounds, as a common pool resource, is considered as inclusion. On the other hand, from the developmental perspective, social inclusion can be defined by one's opportunities to 
interact with others and his/her participation in activities, including sense of belonging and well-being (Hall 2010). From this perspective, social inclusion represents more than mere physical presence, but the participation and engagement in the mainstream society (Cobigo et al. 2012).

The guiding principle of the Prud'homies of granting access to the resources of lagoons to families in need can no longer be upheld. "If you bring on board everyone in need of rescue, the boat will sink" (Hardin, 1974). Due to the rarity of fish stock the boundaries of the fishing society has to be set somewhere. Technology has not been an issue in the case of number of fishers in Prud'homies as "the pace of technological change tends to be relatively slow in the Mediterranean, the effect being to cushion the level of social disruption in terms of organization of labor and eventual loss of employment resulting from innovations" (Bonzon 2000). This fact has been realized by the fishers of lagoon of Thau, consequently restricting even the harvesting urchins to divers registered in the Prud'homie. Therefore, the Prud'homies are still partially practicing their "right to exclusion" (Schlager and Ostrom 1992) but they no longer exclusively determine how many fishers or boats may be active in the lagoon. In line with UN's Sustainable Development Goals, and based on Rawl's (1971) "principle of difference", which advocates the access to scarce resources and space, Prud'homies work to the advantage of those who are worst off. This right has been transferred to the EU by the application of "entry-exit regimes" (EC 2002). Based on this policy, the total capacity of each member states' fleets, expressed in terms of tonnage and engine power, cannot exceed the reference level of year 2003 (Article 11, 12\& 13 of Council Regulation 2371/2002). At the port level, it's the departmental delegation of the fishery who is in charge of the allocation of available quota, allowing the applicant to enter the fishing area under administration of the port of registration. However, separate permission is required from the Prud'homies in order to fish in the lagoon. Inclusion and exclusion need to be balanced and for this, governors need meta-governance principles that stakeholders find legitimate and can agree on (Kooiman and Jentoft, 2009 In Bavinck et al. 2015). However sometimes, the machinations of inclusion and exclusion can be devious and dirty, with the wrong people sometimes being included and the right people being left aside (Bavinck et al. 2015). The criteria of entrance in the case of the Port of Sète is precedence. Whoever has applied previously is admitted as soon as the required quota is released.

Principles of good governance emphasize openness and stakeholder participation through inclusion (Jentoft and Chuenpagdee, 2015). Agents who are included in the fishery governance system determine the structure of co-management. Inclusive governance is based on the assumption that all stakeholders have something to contribute to the process of risk governance and that mutual communication and exchange of ideas, 
assessment and evaluation improve the final decision (Renn 2008). If the local fishers, who have updated information of the resource's conditions and have direct interest in the quality of resources, are excluded from the process of decision making then the goals of good governance would hardly be reachable. Based on the categories of users upon rights that they exercise (table 2), the Prud'homies have been demoted from the position of proprietor to claimant by losing part of their rights after the implementation of exitentry regime (EC 2002).

Table 2: Bundles of rights associated with positions

\begin{tabular}{|l|c|c|c|c|}
\hline & Owner & Proprietor & Claimant & $\begin{array}{l}\text { Authorized } \\
\text { User }\end{array}$ \\
\hline Access and withdrawal & $\mathrm{X}$ & $\mathrm{X}$ & $\mathrm{X}$ & $\mathrm{X}$ \\
\hline Management & $\mathrm{X}$ & $\mathrm{X}$ & $\mathrm{X}$ & \\
\hline Exclusion & $\mathrm{X}$ & $\mathrm{X}$ & & \\
\hline Alienation & $\mathrm{X}$ & & & \\
\hline
\end{tabular}

Source: Schlager and Ostrom 1992

\subsection{Power and voice}

Numerous participative projects value the principle that identifying the stakeholders and gathering them around a table is adequate to obtain a fair consensus. This principle is not valid unless we assume that the concerned actors have the same power of negotiation (Nelson and Wright 1995). State authorities and managers can deal only with entities and their representatives that in fundamental ways embody a mutual understanding of what is important, employ a common worldview and language to express it, and make decisions in a manner consistent with neoliberal administrative practices and objectives (Ralston Saul 1992 In Davis and Ruddle 2012). On the other hand, when co-management is initiated by the government and the main partners are lobby groups or other non-community actors there is a risk of ignoring community values and perspectives (Berkes and Nayak 2018). In fisheries governance, the state thus often has a role to play in making sure that the process and outcomes are inclusive. Otherwise, the most powerful of stakeholders are likely to pull up the ladder while they climb it (Bavinck et al. 2015). When the governance system is considered to be the sovereign, individuals are limited in exploiting the resources to an acceptable extent. Here, the question raised is: "who is the more legitimate party to govern the fishery system?”, "to whom should we transfer the sovereignty of managing marine resources?” Singleton and Taylor (1992) theorize that the types of solutions that result will depend on the degree of community: at one extreme are fully decentralized, endogenous solutions, which depend on high degrees of community; at the other, solutions heavily dependent on the state, because of low degrees of community, and hybrids such as co-management.

Among the 162 fishers of Prud'homies interviewed by Chaboud et al. (2015) 82 of them considered the quality of actions of the European Commission poor concerning the SSF. The same number of people perceives a high quality of performance from local and regional institutes. The majority of small-scale fishers of south France responded that the quota and access restrictions have no effect or a negative effect on the management of fisheries (Chaboud et al. 2015). These statements seem to be a part of the game. They benefit from any tribune to renounce the conservation policies and gain more profit. By asking their perception verbally, they have the 
tendency to describe a dramatic situation and ask for more support. When discussing co-management, it is crucial to distinguish between exercising a right at the operational level and the right at a collective-choice level (Schlager and Ostrom 1992). A strong central governance system may provide structure to the development of regulations, and thus enhance co-management, but local community attributes are also necessary for success (Gutiérrez et al. 2011). As a universal European policy does not correspond to the characteristics of Mediterranean fisheries (Teran Perez 2000), the local fishing communities attempt to modify it to conform to their reality. One of the main arguments of the Prud'homies regarding fisheries sustainability was the need for local governance and the realization that EU policies' "one-size-fits-all approach" does not respect the balance between the policy and the local socialecological characteristics of the fishery (Gutiérrez 2013).

It is inevitable to discuss "voice" when dealing with negotiation and interactions of local and state level authorities. Having voice, as an indicator of being included in collective identity, is discussed in political science as democracy and in social psychology as social cohesion. However broadly speaking, voice remains undertheorized as there is very little consensus on how to measure it or even its feasibility (Lawy 2017). Critics have argued that voice offers "only superficial forms of inclusion", thereby "essentializing group identities" and failing to address "the problem of power in the selective bestowing of voice" (McLeod, 2011: 179). Theory of voice is not only about speaking, participating or making yourself heard, but also must consider the implications of using a voice that relies upon dominant structures to legitimize it (Lawy 2017). The Prud'homies have no official recognition in the French fisheries management framework (Gutiérrez 2013). To have a voice is not only about maintaining or claiming a political agenda as a group but is also a "key representational trope for identity, power, conflict, social position and agency" (Weidman, 2014: 39). Depending on how much responsibility (or right) is assigned to Prud'homies, their position in fishery governance (table 2 ) would be determined. Formal management, compatible with scientific findings, cannot function as efficiently as the local agreements in the field (Jentoft 2006). The knowledge of how a marine ecological system functions is acquired by local fishers through succession and years of close observation. This expertise puts them in a position where SSFs are able to decide spontaneously on how to react in order to sustain the resources and eventually to maintain their fishing activity.

\section{Conclusions}

Key attributes of co-management can be found in local based management (Gutierrez 2011). Pre-modern fishers' organizations could contribute to management with their local knowledge, create social order, solve conflicts and assist in regulating fishing effort (Bavinck et al. 2015; Raicevich 2018). However, adaptation to the current economic and political context is necessary to be compatible with the changes in the social-ecological system. In the neoliberal management system, in order to stay in the game, they have no other choice but to negotiate for rights in the management of fisheries. Otherwise, their exclusion from managerial sphere not only creates a governance system hostile to them but also threatens the marine ecological system. Fishers are as much guardians of the 
sea as the farmers are of the land. Organizing SSF to participate in the management of marine resources is an attempt to include the knowledge of this stakeholder in the decision-making process. New capacities are required to be attained by representatives of local fishing communities (the Prud'homies in the case of our study) in order to be able to negotiate the terms of agreements for the management of marine resources under their jurisdiction.

Conversely to the EU's declared commitment to regionality, the Prud'homies, as local entities of management, are losing their position. Other regional organizations are created and are regularly substituting the traditional role played by the Prud'homies in the decision making and operating the rules. If the solutions to the tragedy of commons does not arise from direct users of resources, then it would not be surprising that a higher-level authority takes over and implements protection strategies in order to conserve the resources for future generations. Local fishers, as the direct beneficiaries of ecological health of marine areas, need to assume their responsibility as guardians of the sea and lagoons and it is up to the governing entity to grant them this authority.

The intrinsic goal of the Common Fishery Policies seems to be to decrease the impacts of transition on less adaptive components of fishery systems. This can be achieved by slowing down the speed of transition for those lagging behind to allow them to catch up with the rest and by providing an appropriate environment to adapt to the new conditions. "A key component of the transition is to minimize risk by developing the capacity for the system to learn as it goes" (Mahon et al. 2008 p.110).

An obstacle to this study was the fishers' concern about the use of the results of the research which prevented them to participate in the meetings. This has been overcome through a year of correspondence to convince the neutrality of the research group towards the topic. The lack of trust between the fishers and the official system of management in itself is an indication of the rivalry of the two on the subject of management of marine resources.

Conflict of interest statement: on behalf of all authors, the corresponding author states that there is no conflict of interest.

\section{References}

Agrawal, Arun. 2002. Common resources and institutional sustainability. In: Ostrom, E., Dietz, T., Dolsak, N., Stern, P.C., Stonich, S., Weber, E.U. (Eds.), The Drama of the Commons. National Academy Press, Washington, DC, pp. 41-85.

Baland, Jean-Marie and Jean-Philippe Platteau. 1996. Halting Degradation of Natural Resources: Is There a Role for Rural Communities? Clarendon, Oxford.

Bavinck, Maarten, Ratana Chuenpagdee, Svein Jentoft, and Jan Kooiman, ed. 2013. Governability of Fisheries and Aquaculture. Vol. 7. MARE Publication Series. Dordrecht: Springer Netherlands. doi:10.1007/97894-007-6107-0.

Bavinck, Maarten, Subramanian Karuppiah, and Svein Jentoft. 2015. Contesting Inclusiveness: The Anxieties of Mechanised Fishers Over Social Boundaries in Chennai, South India. The European Journal of Development Research 27: 589-605. doi:10.1057/ejdr.2015.46. 
Berkes, Fikret. 2006. From community-based resource management to complex systems: the scale issue and marine commons. Ecology and Society 11.

Berkes, Fikret. 2009. Evolution of co-management: Role of knowledge generation, bridging organizations and social learning. Journal of Environmental Management 90: 1692-1702. doi:10.1016/j.jenvman.2008.12.001.

Berkes, Fikret, and Prateep Kumar Nayak. 2018. Role of communities in fisheries management: "one would first need to imagine it.” Maritime Studies 17: 241-251. doi:10.1007/s40152-018-0120-x.

Bethelot, Sabin. 1868. Etude sur les pêches maritimes dans la Méditerranée et l’océan. Paris : Challamel Ainé.

Bonzon, Alain. 2000. Development of economic and social indicators for the management of Mediterranean fisheries. Marine and Freshwater Research 51: 493. doi:10.1071/MF99088.

Broch, Harald Beyer. 2013. Social resilience-local responses to changes in social and natural environments. Maritime Studies 12: 6.

Bulletin des Lois de la République Française, 1852, Paris : Impremerie National.

Cépralmar. 2013. Atlas des pêches du Languedoc-Roussillon, La région Languedoc-Roussillon.

Carrà Giuseppina, Monaco Clara and Peri Iuri. 2017. Local management plans for sustainability of small-scale fisheries. Quality-Access to Success 18(S2). ISSN I582-2559.

Cazalet, Bertrand and Chloë Webster. 2014. Integration of small-scale fisheries in Marine Protected Areas (MPAs) - GFCM/MedPAN. In FAO. 2014. First Regional Symposium on Sustainable Small-Scale Fisheries in the Mediterranean and Black Sea. St Julian's, Malta, 27-30 November 2013. FAO fisheries and Aquaculture proceedings.

Cobigo, Virgine, Hélène Ouellette-Kuntz, Rosemary Lysaght and Martin Lynn. 2012. Shifting our conceptualization of social inclusion. Stigma Research and Action, Vol 2, No 2, 75-84.

Cooley, Charles H. 1918. Social process. NewYork: C. Scribner's Sons.

Coser, Lewis A. 1956. The functions of social conflict. Percy Lund, Humphreys and Co. Ltd. London.

Chaboud, Christian, Bertrand CAZALET, Nastassia REYES, and Alex RUBIN. 2015. Enquête sur les petits métiers de la pêche en Languedoc-Roussillon.

Chuenpagdee, Ratana and Robin Mahon. 2013. Approaches and Tools for Examining Governability In Maarten Bavinck et al. (eds.), Governability of Fisheries and Aquaculture: 265 Theory and Applications, MARE Publication Series 7, Springer Science+Business Media Dordrecht 2013

Commission for Environmental Cooperation. 2002. Proposal for a Council Regulation on the Conservation, Exploitation of Fisheries Resources under the Common Fisheries Policy, COM (2002) 185 final, Brussels, 28 May 2002.

Coulthard, Sarah. 2012. What does the debate around social wellbeing have to offer sustainable fisheries? Current Opinion in Environmental Sustainability 4: 358-363. doi:10.1016/j.cosust.2012.06.001.

Crawford, Adam. 2001. Vers une reconfiguration des pouvoirs? Déviance et société 25: 3-32.

Davis, Anthony, and Kenneth Ruddle. 2012. Massaging the Misery: Recent Approaches to Fisheries Governance and the Betrayal of Small-Scale Fisheries. Human Organization 71: 244-254. JSTOR.

Decugis, Christian. 2015. Mediterranean Prud’homies. In: Ceccaldi HJ., Hénocque Y., Koike Y., Komatsu T., Stora G., Tusseau-Vuillemin MH. (eds) Marine Productivity: Perturbations and Resilience of Socioecosystems. Springer, Cham

Eggins, Racheal Anne. 1999. Social identity and social conflict: negotiating the path to resolution, Ph.D. thesis, Australian National University.

EC. 2002. Council Regulation (EC) No 2371/2002 of 20 December 2002 on the conservation and sustainable exploitation of fisheries resources under the Common Fisheries Policy

EU. 2009. GREEN PAPER Reform of the Common Fisheries Policy. Brussels.

Fisher Roger and William Ury. 1982. Comment réussir une négociation? Paris: Seuil.

Borrini-Feyerabend, Grazia. 2000. Co-management of Natural Resources: Organising, Negotiating and Learning by Doing, IUCN, Yaoundé, Cameroon.

Folke, Carl, Steve R. Carpenter, Thomas Elmqvist, Lance H. Gunderson, C.S. Holling, Brian H. Walker. 2002. Resilience and Sustainable Development: Building Adaptive Capacity in a World of Transformations. AMBIO: A Journal of the Human Environment 31(5), 437-440.

Geertz, Clifford. 1973. Thick description: toward an interpretive theory of culture. New York : Fontana Press.

Giovannoni Vincent. 1995. Les pêcheurs de l'étang de Thau: écologie humaine et ethnologie des techniques. Paris: L'Harmattan.

Hechter, Micheal and Christine Horne. 2008. The problem of social order, Stanford University Press.

Holling C.S. 1973. Resilience and stability of ecological systems. Annual Review of Ecology and Systematics 4, pp. 1-23.

Gray, Tim, and Jenny Hatchard. 2003. The 2002 reform of the Common Fisheries Policy’s system of governance —rhetoric or reality? Marine Policy 27: 545-554. doi:10.1016/S0308-597X(03)00066-6. 
Gutiérrez, Nicolás L., Ray Hilborn, and Omar Defeo. 2011. Leadership, social capital and incentives promote successful fisheries. Nature 470: 386-389. doi:10.1038/nature09689.

Gutiérrez Nicolas L. 2013. Management and co-management options for small-scale fisheries in the Mediterranean and Black sea, In FAO. 2014. First Regional Symposium on Sustainable Small-Scale Fisheries in the Mediterranean and Black Sea. St Julian's, Malta, 27-30 November 2013. FAO fisheries and Aquaculture proceedings.

Hall, E. 2010. Spaces of social inclusion and belonging for people with intellectual disabilities. Journal of Intellectual Disability Research 54: 48-57. doi:10.1111/j.1365-2788.2009.01237.x.

Hardin, Garrett. 1968. The Tragedy of the Commons. Science 162: 1243-1248. doi:10.1126/science.162.3859.1243.

Hayek, Friedrich August. 1980. Individualism and economic order. University of chicago Press.

Hilborn, Ray. 2007. Managing fisheries is managing people: what has been learned? Fish and Fisheries 8: 285296.

Hoppe, Robert. 2005. Rethinking the science-policy nexus: from knowledge utilization and science technology studies to types of boundary arrangements. Poiesis \& Praxis 3: 199-215. doi:10.1007/s10202-0050074-0.

Jentoft Svein, Bonnie J. McCay, Douglas C. Wilson. 1998. Social theory and fisheries co-management. Mar Policy 22:423-436.

Jentoft, Svein. 2000. Legitimacy and disappointment in fisheries management. Marine policy 24: 141-148.

Jentoft, Svein. 2006. Beyond fisheries management: The Phronetic dimension. Marine Policy 30: 671-680. doi:10.1016/j.marpol.2005.10.001.

Jentoft, Svein, and Ratana Chuenpagdee. 2009. Fisheries and coastal governance as a wicked problem. Marine Policy 33: 553-560.

Jentoft, Svein, Arne Eide, Maarten Bavinck, Ratana Chuenpagdee and Jesper Raakjaer. 2011. A better future: Prospects for small-scale fishing people. In Poverty mosaics: Realities and prospects in small-scale fisheries, ed. Svein Jentoft and Arne Eide, 451-469. New York: Springer.

Jentoft, Svein. 2011. Roots and wings. Samudra Report 60: 17-22.

Jentoft, Svein and Ratana Chuenpagdee. 2015. Interactive governance for small-scale fisheries. Global Reflections: Springer.

Johnson, Derek, Maarten Bavinck, Joeli Veitayaki. 2005. Fish Capture In Kooiman Jan, Maarten Bavinck, Svein Jentoft, Roger Pullin. 2005. Fish for life: interactive Governance for fisheries. Amsterdam University Press.

Johnson, Derek S. 2018. The Values of Small-Scale Fisheries. In Social Wellbeing and the Values of Small-scale Fisheries, ed. Derek S. Johnson, Tim G. Acott, Natasha Stacey, and Julie Urquhart, 17:1-21. Cham: Springer International Publishing. doi:10.1007/978-3-319-60750-4_1.

Kooiman, Jan and Ratana Chuenpagdee. 2005. Governance and governability In Kooiman Jan, Bavinck Maarten, Jentoft Svein, Pullin Roger. 2005. Fish for life: interactive Governance for fisheries, Amsterdam University Press.

Lassiter, Charles, Vinai Norasakkunkit, Benjamin Shuman, and Tuukka Toivonen. 2018. Diversity and Resistance to Change: Macro Conditions for Marginalization in Post-industrial Societies. Frontiers in Psychology 9. doi:10.3389/fpsyg.2018.00812.

Lawy, Jenny R. 2017. Theorizing voice: Performativity, politics and listening. Anthropological Theory 17: 192215. doi:10.1177/1463499617713138.

Lindkvist, Emilie, Xavier Basurto, and Maja Schlüter. 2017. Micro-level explanations for emergent patterns of self-governance arrangements in small-scale fisheries-A modeling approach. PloS one 12: e0175532.

Mahon, Robin, Patrick McConney, and Rathindra N. Roy. 2008. Governing fisheries as complex adaptive systems. Marine Policy 32: 104-112. doi:10.1016/j.marpol.2007.04.011.

Markussen, Peter, and Gert Tinggaard Svendsen. 2005. Industry lobbying and the political economy of GHG trade in the European Union. Energy Policy 33: 245-255. doi:10.1016/S0301-4215(03)00238-6.

McLeod Julie. 2011. Student voice and the politics of listening in higher education. Critical Studies in Education 52(2): 179-189.

Melitz, Marc J. 2003. The impact of trade on intra-industry reallocations and aggregate industry Productivity. Econometrica, 71 (6): 1695-1725.

Meyer, Jean .2000. De la pêche en Méditerranée: de quelques problèmes de géo-histoire In La pêche en Méditerranée, Les cahiers du Centre d’études et de rencontres méditerranéennes, Tome 2, Palavas-lesflots.

Monaco Clara, Caballé Marta and Peri Iuri. 2019. Preliminary study on interaction between dolphins and smallscale fisheries in Sicily: learning mitigation strategies from agriculture. Quality-Access to Success 20(S2): 400407. 
Nelson, Nici, and Susan Wright. 1995. Power and Participatory Developement : Theory and practice, Intermediate Technology Publications, 225 pages.

Norton, Bryan G. 2012. The Ways of Wickedness: Analyzing Messiness with Messy Tools. Journal of Agricultural and Environmental Ethics 25: 447-465. doi:10.1007/s10806-011-9333-3.

Ostrom, Elinor. 1990. Governing the Commons: The Evolution of Institutions for Collective Action, Cambridge University Press, Cambridge, UK.

Ostrom, Elinor. 2009. A general framework for analyzing sustainability of social-ecological systems. Science 325: 419-422. doi:10.1126/science.1170749.

Pascual-Fernández, José J., Raquel De la Cruz Modino, Ratana Chuenpagdee, and Svein Jentoft. 2018. Synergy as strategy: learning from La Restinga, Canary Islands. Maritime Studies 17: 85-99. doi:10.1007/s40152-018-0091-y.

Picker, Giovanni. 2017. Social Inclusion/Exclusion. In The Wiley-Blackwell Encyclopedia of Social Theory, 1-3. American Cancer Society. doi:10.1002/9781118430873.est0532.

Pollnac, Richard B. 1988. Social and cultural characteristics of fishing peoples. Mar Behav Physiol, 14:23-39.

Pomeroy, Robert, John Parks, Kitty Courtney, and Nives Mattich. 2016. Improving marine fisheries management in Southeast Asia: Results of a regional fisheries stakeholder analysis. Marine Policy 65: 20-29. doi:10.1016/j.marpol.2015.12.002.

Raicevich, S., J.-L. Alegret, K. Frangoudes, O. Giovanardi, and T. Fortibuoni. 2018. Community-based management of the Mediterranean coastal fisheries: Historical reminiscence or the root for new fisheries governance? Regional Studies in Marine Science 21: 86-93. doi:10.1016/j.rsma.2017.10.013.

Rawls, John. 1971. A Theory of Justice. Cambridge, MA: Harvard University Press.

Rittel, Horst W. J., and Melvin M. Webber. 1973. Dilemmas in a general theory of planning. Policy Sciences 4: 155-169. doi:10.1007/BF01405730.

Reynaud, Jean-Daniel. 1997. Les Règles du jeu: L'action collective et la régulation sociale. Paris : Armand Colin.

Salomon, Markus, Till Markus, and Miriam Dross. 2014. Masterstroke or paper tiger - The reform of the EU's Common Fisheries Policy. Marine Policy 47: 76-84. doi:10.1016/j.marpol.2014.02.001.

Schlager Edella, and Elinor Ostrom. 1992. Property-rights regimes and natural resources: a conceptual analysis. Land Economics 68 (3): 249-262.

Simmel, Georg. (1955) Conflict. New York: The Free Press.

Singleton, Sara, and Michael Taylor. 1992. Common Property, Collective Action and Community. Journal of Theoretical Politics 4: 309-324. doi:10.1177/0951692892004003004.

Solich, Martin, and Marcel Bradtmöller. 2017. Socioeconomic complexity and the resilience of hunter-gatherer societies. Quaternary International 446: 109-127. doi:10.1016/j.quaint.2017.06.064.

Song, Andrew M., Chuenpadgee Ratana. 2015. The damage schedule approach in M. Bavinck et al. (eds.), Governability of Fisheries and Aquaculture: 265 Theory and Applications, MARE Publication Series 7, Springer Science+Business Media Dordrecht 2013

Song, Andrew M., Hekia Bodwitch, and Joeri Scholtens. 2018. Why marginality persists in a governable fishery —-the case of New Zealand. Maritime Studies 17: 285-293. doi:10.1007/s40152-018-0121-9.

Stephenson, Geoffrey M. 1984. Intergroup and interpesronal dimensions of bargaining and negotiation. In $\mathrm{H}$. Tajfel, Social Dimensions, Volume 2, Cambridge : Cambridge University Press.

Sword-Daniels, V.L., J. Twigg, and S.C. Loughlin. 2015. Time for change? Applying an inductive timeline tool for a retrospective study of disaster recovery in Montserrat, West Indies. International Journal of Disaster Risk Reduction 12: 125-133. doi:10.1016/j.ijdrr.2014.12.006.

Syndicat mixte du bassin de Thau. 2013. Contrat de gestion intégrée 2012-2017. https://www.smbt.fr/content/programme-dactions-0 Accessed 1st on June 2019.

Vindigni Gabriella, Carrà Giuseppina and Monaco Clara. 2016. Which approach for sustainable development of small-scale fisheries? The case of Italy. Quality-Access to Success 17: 142-148.

Vollan, Bjørn. 2008. Socio-ecological explanations for crowding-out effects from economic field experiments in southern Africa. Ecological Economics 67: 560-573. doi:10.1016/j.ecolecon.2008.01.015.

Teran Perez Y. 2000. L'inadaptation du droit international de la mer à la pêche en Méditerranée in La pêche en Méditerranée. Les cahiers du Centre d'études et de rencontres méditerranéennes, Tome 2, Palavas-lesflots.

Tönnies, Ferdinand. 1887. Gemeinschaft und Gesellschaft. Translated and edited by Charles P. Loomis (1957) Community and Society: East Lansing, Michigan: Michigan State University Press.

Walker, Brian, C. S. Holling, Stephan. R. Carpenter, and Anna Kinzig. 2004. Resilience, adaptability and transformability in social-ecological systems. Ecology and Society 9(2): 5.

Watzlawick, Paul, John H. Weakland, and Richard Fisch. 2011. Change: Principles of problem formation and problem resolution. WW Norton \& Company.

Weidman, Amanda. 2014. Anthropology and voice. Annual Review of Anthropology 43: 37-51. 
Whyte, Kyle Powys, and Paul B. Thompson. 2012. Ideas for How to Take Wicked Problems Seriously. Journal of Agricultural and Environmental Ethics 25: 441-445. doi:10.1007/s10806-011-9348-9. 